\title{
Corrigendum
}

\section{Corporate Reputation and Financial Performance of Life Insurers}

\author{
Tsai-Jyh Chen
}

The Geneva Papers (2016) 41, 528. doi:10.1057/gpp.2016.13; published online 13 April 2016

Correction to: The Geneva Papers on Risk and Insurance-Issues and Practice (2016) doi:10.1057/gpp.2016.8; published online 16 March 2016

This article has been corrected as of 13 April 2016. The definition of ROI in Table 1 on page 8 was erroneously published and has now been amended to the following:

$2 \times$ net investment incomes/( $2 \times$ mean total assets-net investment incomes) of firm $i$ in year $t$ No other element of the article is under question.

Table 1 Definitions of the variables

\begin{tabular}{ll}
\hline Variable & Definition \\
CorpRP $_{i, t}$ & $=$ score of recommendation of firm $i$ in year $t$ \\
$\operatorname{lnExp}_{i, t}$ & $=\ln$ (business expenses) of firm $i$ in year $t$ \\
Complaints $_{i, t}$ & $=$ no. of complaints/no. of contracts in force of firm $i$ in year $t$ \\
ROA $_{i, t}$ & $=$ net incomes/mean total assets of firm $i$ in year $t$ \\
Debtr $_{i, t}$ & $=$ total liabilities/total assets of firm $i$ in year $t$ \\
$F H C_{i, t}$ & $=1$ if firm $i$ in year $t$ is a subsidiary of a financial holding co. \\
$F I_{i, t}$ & $=1$ if firm $i$ in year $t$ with $>50 \%$ of equities held by foreigners \\
$\operatorname{lnPremNC}_{i, t}$ & $=\ln$ (premium incomes of new contracts) of firm $i$ in year $t$ \\
ROI $_{i, t}$ & $=2 \times$ net investment incomes/(2 $\times$ mean total assets-net investment incomes) of firm $i$ in year $t$ \\
\hline
\end{tabular}

